\title{
PENINGKATAN KOMPETENSI GURU DALAM PENGINPUTAN PENILAIAN E-RAPORT MELALUI PELATIHAN TIK DI SDN-I PANGKALAN SATU TAHUN PELAJARAN 2019/2020"
}

\author{
Improving Teachers 'Competency In Evaluation Inputing E-Raport Through Ict Training At SDN-I \\ Pangkalan One Study Year 2019/2020 "
}

Mansyur, S.Pd SD *

*, SDN-I Pangkalan, Kalimantan Tengah, Indonesia.

\section{Kata Kunci: \\ Hasil Belajar, Menyusun Instrumen, Aplikasi E- Raport.}

\section{Keywords:}

Learning Outcomes, Compiling Instruments, EReport Card Application.

\section{Accepted}

September 2020

\section{Published}

December 2020

\begin{abstract}
Abstrak
Penilaian hasil belajar dimulai dengan merencanakan penilaian, menyusun instrumen, melaksanakan penilaian, mengolah dan memanfaatkan, serta melaporkan hasil penilaian. E-Raport sebagai muara akhir dari proses penilaian yang dilakukan pada seluruh proses pada satuan pendidikan.

Aplikasi E-Raport yang telah diluncurkan oleh Kemendikbud baik untuk SD/MI, SMP/MTs, SMA/MA dan SMK telah berlangsung kurang lebih 3 tahun. Guru disibukkan dengan tugasnya sebagai pendidik, dimana guru dalam fungsi tugasnya Merencanakan, Mengajar, Mendidik dan Melakukan Evaluasi atau Penilaian terhadap peserta didik di setiap akhir semester.

Kalau selama ini penilaian dilakukan secara manual yaitu guru menuliskan Raport dengan menggunakan tinta pulpen, setelah diluncurkan E-Raport maka penilaian Raport di lakukan dengan digital dimana guru harus merencanakan penilaian dan melakukan penilaian secara semi online. Penilaian E-Rapor memiliki tingkat keribetan yang tinggi ketika sudah berhadap KI3 di bandingkan KTSP.

Oleh karenanya peneliti di sini hendak meningkatkan kompetensi guru dalam penginputan penilaian eraport melalui pelatihan TIK. Pelatihan adalah suatu proses dimana orang-orang mencapai kemampuan tertentu untuk membantu mencapai tujuan organisasi. Oleh karena itu, proses ini terikat dengan berbagai tujuan organisasi, pelatihan dapat dipandang secara sempit maupun luas. Secara terbatas, pelatihan menyediakan para pegawai dengan pengetahuan yang spesifik dan dapat diketahui serta keterampilan yang digunakan dalam pekerjaan mereka saat ini. Terkadang ada batasan yang ditarik antara pelatihan dengan pengembangan, dengan pengembangan yang bersifat lebih luas dalam cakupan serta memfokuskan pada individu untuk mencapai kemampuan baru yang berguna baik bagi pekerjaannya saat ini maupun di masa mendatang.
\end{abstract}

\footnotetext{
Abstract

Assessment of learning outcomes begins with planning the assessment, compiling instruments, carrying out assessments, processing and utilizing, and reporting the results of the assessment. E-Raport as the final estuary of the assessment process carried out in the entire process in the educational unit.

The E-Raport application that has been launched by the Ministry of Education and Culture for SD / MI, SMP / MTs, SMA / MA and SMK has been going on for about 3 years. Teachers are preoccupied with their duties as educators, where teachers are in the function of Planning, Teaching, Educating and Evaluating or Assessing students at the end of each semester.

If all this time the assessment was done manually, namely the teacher wrote the report card using pen ink, after the E-report card was launched, the report card assessment was done digitally where the teacher had to plan the assessment and do the assessment semi online. The E-Report Card assessment has a high level of fuss when it comes to KI3 compared to KTSP.

Therefore, researchers here want to improve teacher competence in inputting e-raport assessments through ICT training. Training is a process by which people achieve certain abilities to help achieve organizational goals. Therefore, this process is tied to various organizational goals, training can be viewed both narrowly and broadly. To a limited extent, training provides employees with specific and identifiable knowledge and skills used in their current jobs. Sometimes there are boundaries drawn between training and development, with development that is broader in scope and focuses on the individual to achieve new abilities that are useful both for his current and future work.
} 


\section{KAJIAN TEORI DAN HIPOTESIS TINDAKAN \\ A. Kajian Teori}

A) Kompetensi Guru

\section{Pengertian Kompetensi Guru}

Kompetensi dalam Bahasa Indonesia merupakan serapan dari bahasa Inggris, competence yang berarti kecakapan dan kemampuan (Musfah, 2015:27). Kompetensi adalah kumpulan pengetahuan, perilaku, dan keterampilan yang harus dimilki guru untuk mencapai tujuan pembelajaran dan pendidikan. Kompetensi berarti kemampuan mewujudkan sesuatu sesuai dengan tugas yang diberikan kepada seseorang. Kompetensi juga terkait dengan standar dimana seseorang dikatakan kompeten dalam bidangnya jika pengetahuan, keterampilan, dan sikap serta hasil kerjanya sesuai standar (ukuran) yang ditetapkan dan/atau diakui oleh lembaganya/pemerintah. Musfah (2015:27) hakikat kompetensi adalah kekuatan mental dan fisik untuk melakukan tugas atau keterampilan yang dipelajari melalui latihan dan praktek. Dari hal ini maka suatu kompetensi dapat diperoleh melalui pelatihan dan pendidikan.

\section{Kompetensi Pedagogik}

Menurut Musfah (2015:30) kompetensi pedagogik adalah kemampuan dalam pengelolaan peserta didik yang meliputi (a) pemahaman wawasan atau landasan kependidikan; (b) pemahaman tentang peserta didik; (c) pengembangan kurikulum atau silabus; (d) perancangan pembelajaran; (e) pelaksanaan pembelajaran yang mendidik dan dialogis; ( $f$ ) evaluasi hasil belajar; dan $(\mathrm{g})$ pengembangan peserta didik untuk mengaktualisasikan berbagai potensi yang dimilikinya.

\section{Kompetensi Kepribadian}

Dalam jurnal Pengembangan Kepribadian Guru (Nursyamsi, 2014) Kartono (2005:9) menjelaskan bahwa kepribadian itu secara langsung berhubungan dengan kapasitas psikis seseorang ; berkaitan dengan nilai-nilai etis atau kesusilaan dan tujuan hidup. Kepribadian itu manusia itu juga selalu mengandung unsur dinamis, yaitu ada kemajuan-kemajuan atau progress menuju suatu integrasi baru tapi system psikofisis tersebut tidak pernah akan sempurna bisa terintegrasi dengan sempurna. Kepribadian ini mencakup kemampuan adaptasi (menyesuaikan diri) yang karakteristik terhadap lingkungan.

\section{B) Penginputan Penilaian E-Raport}

Rapor merupakan dokumen yang menjadi penghubung komunikasi antara sekolah dengan orang tua peserta didik. Dokumen ini juga menghubungkan sekolah dengan pihak-pihak lain yang ingin mengetahui tentang hasil belajar anak pada kurun waktu tertentu. Karena itu, rapor harus komunikatif, informatif, dan komprehensif (menyeluruh), dalam memberikan gambaran tentang hasil belajar peserta didik.

Rapor berasal dari kata dasar report yang berarti laporan. Rapor merupakan laporan hasil dari suatu kegiatan yang disusun secara benar. Materi yang dilaporkan dalam hal ini adalah hasil ulangan harian, tugas harian, ujian tengah semester, ujian akhir semester, kepribadian, ekstrakulikuler beserta data yang diperlukan yang berkaitan dengan rapor.

Rapor setiap semester adalah sesuatu yang dinantikan oleh setiap siswa di sekolah. Bagi sekolah, proses menghasilkan rapor adalah agenda besar dan rutin di setiap semester. Proses penginputan nilai, perhitungan nilai, hingga penggabungan nilai dari berbagai guru mata pelajaran menjadi proses yang harus presisi dan terkadang memakan waktu.

\section{C) Pelatihan TIK}

\section{a. Pelatihan \\ I. Pengertian Pelatihan}

Menurut Rivai (2005:225), pelatihan adalah proses secara sistematis mengubah tingkah laku pegawai untuk mencapai tujuan organisasi.Pelatihan berkatian dengan keahlian dan kemampuan pegawai untuk melaksanakan pekerjaan saat ini. Pelatihan memiliki orientasi saat ini dan membantu pegawai untuk mencapai kehalian dan kemampuan tertentu agar berhasil dalam melaksanakan pekerjaanya.

Menurut Siagian dalam Lubis (2008:28) definisi pelatihan adalah: proses belajar mengajar dengan menggunakan teknik dan metode tertentu secara konsepsional dapat dikatakan bahwa latihan dimaksudkan untuk meningkatkan keterampilan dan kemampuan kerja seseorang atau sekelompok orang. Biasanya yang sudah bekerja pada suatu organisasi yang efisiensi, efektivitas dan produktivitas kerjanya dirasakan perlu untuk dapat ditingkatkan secara terarah dan pragmatik.

Menurut Bernadin dan Russel dalam Gomes (2003:197), pelatihan adalah setiap usaha untuk memperbaiki performasi tanggungjawabnya, atau satu pekerjaan yang ada kaitannya dengan pekerjaannya.

\section{Tujuan Pelatihan}

Menurut Carrel dalam Salinding (2011:15) mengemukakan delapan tujuan utama program pelatihan antara lain:

a) Memperbaiki kinerja.

b) Meningkatkan keterampilan karyawan.

c) Menghindari Keusangan manajerial.

d) Memecahkan permasalahan.

e) Orientasi karyawan baru.

f) Persiapan promosi dan keberhasilan manajerial

g) Memperbaiki kepuasan untuk kebutuha

h) pengembangan personel karyawannya, maka perlu terlebih dahulu dijelaskan apa yang menjadi sasaran daripada pelatihan tersebut. Dalam pelatihan tersebut ada beberapa sasaran utama yang ingin dicapai.

Menurut Umar dalam Salinding (2011:16) mengemukakan bahwa: "Program pelatihan bertujuan untuk memperbaiki penguasaan berbagai keterampilan dan teknik pelaksanaan kerja untuk kebutuhan sekarang".

Pelatihan juga bertujuan agar peserta pelatihan cepat berkembang, sebab sulit bagi seseorang untuk mengembangkan diri hanya berdasarkan pengalaman tanpa adanya suatu pendidikan khusus. Ini membuktikan 
bahwa pengembangan diri akan lebih cepat melalui palatihan.

\section{Prinsip-prinsip Pelatihan}

Menurut Sofiyandi dalam Probosemi (201 I:22) mengemukakan lima prinsip pelatihan sebagai berikut:

a) Participation, artinya dalam pelaksanaan pelatihan para peserta harus ikut aktif karena dengan partisipasi peserta akan lebih cepat menguasai dan mengetahui berbagai materi yang diberikan.

b) Repetition, artinya senantiasa dilakukan secara berulang karena dengan ulangan-ulangan ini peserta akan lebih cepat untuk memenuhi dan mengingat apa yang telah diberikan.

c) Relevance, artinya harus saling berhubungan sebagai contoh para peserta pelatihan terlebih dahulu diberikan penjelasan secara umum tentang suatu pekerjaan sebelum mereka mempelajari hal-hal khusus dari pekerjaan tersebut.

d) Transference, artinya program pelatihan harus disesuaikan dengan kebutuhan-kebutuhan yang nantinya akan dihadapi dalam pekerjaan yang sebenarnya.

e) Feedback, artinya setiap program pelatihan yang dilaksanakan selalu dibutuhkan umpan balik yaitu untuk mengukur sejauh mana keberhasilan dari program pelatihan tersebut.

\section{b. TIK}

\section{Pengertian Teknologi Informasi}

Teknologi Informasi (TI), atau dalam bahasa Inggris dikenal dengan istilah Information technology (IT) adalah istilah umum yang menjelaskan teknologi apa pun yang membantu manusia dalam membuat, mengubah, menyimpan, mengomunikasikan dan/atau menyebarkan informasi. TI menyatukan komputasi dan komunikasi berkecepatan tinggi untuk data, suara, dan video. Contoh dari Teknologi Informasi bukan hanya berupa komputer pribadi, tetapi juga telepon, TV, peralatan rumah tangga elektronik, dan peranti genggam modern (misalnya ponsel).

Pengolahan, penyimpanan dan penyebaran vokal, informasi bergambar, teks dan numerik oleh mikroelektronika berbasis kombinasi komputasi dan telekomunikasi. Istilah dalam pengertian modern pertama kali muncul dalam sebuah artikel 1958 yang diterbitkan dalam Harvard Business Review, di mana penulis Leavitt dan Whisler berkomentar bahwa "teknologi baru belum memiliki nama tunggal yang didirikan. Kita akan menyebutnya teknologi informasi (TI). ". Beberapa bidang modern dan muncul teknologi informasi adalah generasi berikutnya teknologi web, bioinformatika, "Cloud Computing", sistem informasi global, Skala besar basis pengetahuan dan lain-lain.

\section{Bagian-bagian dan Komponen-} komponen Teknologi Informasi

Komponen teknologi informasi merupakan sub sistem yang terbentuk sehubungan dengan penggunaan teknologi informasi. Untuk dapat memanfaatkan teknologi informasi, umumnya dibutuhkan setidaknya tiga komponen utama :

a. perangkat keras (hardware) b. perangkat lunak (software)

c. manusia (brainware). Untuk perangkat telekomunikasi diasumsikan termasuk dalam komponen hardware.

Perangkat keras disini merupakan perangkat fisik yang membangun sebuah teknologi informasi. Contoh perangkat keras disini misalnya, monitor,keyboard, mouse, printer, harddisk, memori, mikroprosesor, CDROM, kabel jaringan, antenna telekomunikasi, dan lainlain. Untuk teknologi perangkat keras akan dibahas lebih mendalam pada tulisan berikutnya pada categori Teknologi Perangkat Keras, Teknologi Perangkat Input dan Teknologi Perangkat Output.

Perangkat lunak disini merupakan program yang dibuat untuk keperluan khusus. Perangkat lunak dapat dibagi menjadi tiga; perangkat lunak sistem, perangkat lunak bahasa pemrograman, dan perangkat lunak aplikasi.

\section{Sejarah Teknologi Informasi}

Pada awalnya istilah Teknologi Informasi biasa disebut Teknologi komputer atau pengolahan data elektronis (electronic data processing). Istilah Teknologi Informasi sendiri mulai populer di akhir tahun 70-an. Teknologi informasi didefinisikan sebagai Teknologi pengolahan dan penyebaran data menggunakan perangkat keras (hardware) dan perangkat lunak (software), komputer, komunikasi, dan elektronik digital. Perkembangan Teknologi Informasi sangat pesat dipicu oleh kebutuhan informasi secara cepat, tepat, dan terkini. Teknologi Informasi telah menjadi fasilitas utama bagi kegiatan berbagai sector kehidupan dimana memberikan andil besar terhadap perubahan-perubahan yang mendasar pada struktur operasi dan manajemen organisasi, pendidikan, trasportasi, kesehatan dan penelitian.

Pada awal sejarah itu juga, manusia bertukar informasi melalui bahasa. Maka bahasa adalah teknologi, bahasa memungkinkan seseorang memahami informasi yang disampaikan oleh orang lain tetapi itu tidak bertahan secara lama karena Setelah ucapan itu selesai, maka informasi yang berada di tangan si penerima itu akan dilupakan dan tidak bisa disimpan lama. Selain itu jangkauan suara juga terbatas.

Setelah itu teknologi penyampaian informasi berkembang melalui gambar. Dengan gambar jangkauan informasi bisa lebih jauh. Gambar ini bisa dibawa-bawa dan disampaikan kepada orang lain. Selain itu informasi yang ada akan bertahan lebih lama. Beberapa gambar peninggalan zaman purba masih ada sampai sekarang sehingga manusia sekarang dapat (mencoba) memahami informasi yang ingin disampaikan pembuatnya.

Ditemukannya alfabet dan angka arabik memudahkan cara penyampaian informasi yang lebih efisien dari cara yang sebelumnya. Suatu gambar yang mewakili suatu peristiwa dibuat dengan kombinasi alfabet, atau dengan penulisan angka, seperti MCMXLIII diganti dengan 1943. Teknologi dengan alfabet ini memudahkan dalam penulisan informasi itu.

Kemudian, teknologi percetakan memungkinkan pengiriman informasi lebih cepat lagi. Teknologi 
elektronik seperti radio, televisi, komputer mengakibatkan informasi menjadi lebih cepat tersebar di area yang lebih luas dan lebih lama tersimpan.

\section{B. Penelitian Yang Relevan}

Berikut adalah beberapa hasil penelitian yang relevan dengan penelitian tindakan sekolah ini:

I. Jurnal dengan judul "PENINGKATAN KOMPETENSI GURU DALAM PENGINPUTAN PENILAIAN E-RAPORT MELALUI IHT DAN PENDAMPINGAN DI SMA NEGERI 8 BATANG HARI TAHUN PELAJARAN 2019/2020 Oleh: AMIR HUSIN IYUT MARDIATI

Hasilnya adalah: Adapun hasil penelitian menunjukkan bahwa kegiatan yang dilakukan efektif karena dapat meningkatkan kompetensi guru dalam menjalankan perannya sebagai guru pada penginputan nilai pada aplikasi E-Raport, dapat meningkatkan semangat para Guru untuk lebih baik dalam melakukan penialaian terhadap proses serta hasil belajar peserta didik, dapat meningkatkan rasa tanggung jawab tenaga pendidik terhadap beban tugas sebagai Guru, serta memahami tentang pentingnya menjalankan prinsip penilaian, dan mampu memberikan kesempatan bagi guru yang belum terlalu menegrti dalam melakukan penginputan penialaian melalui aplikasi E-Raport.

\section{Kerangka Berfikir}

Kerangka Berpikir adalah sebuah model atau gambaran yang berupa konsep yang didalamnya menjelaskan tentang hubungan antara variabel yang satu dengan varibel yang lainnya.

\section{Hipotesis Tindakan}

Hipotesis diartikan sebagai dugaan sementara pada penelitian yang akan dilakukan. Termasuk dalam pelaksanaan penelitian tindakan kelas, hipotesis dibutuhkan sebagai acuan peneliti, yang disebut dengan hipotesis tindakan.

Hipotesis tindakan dalam penelitian ini adalah pelatihan TIK dapat meningkatkan kompetensi guru dalam penginputan penilaian E-Raport di SDN-I Pangkalan Satu Tahun Pelajaran 2019/2020.

\section{METODE PENELITIAN}

\section{A. Pendekatan Penelitian}

Penelitian ini merupakan penelitian tindakan sekolah (School Action Research), karena penelitian dilakukan untuk memecahkan masalah proses pembelajaran di sekolah. Penelitian ini menggambarkan bagaimana suatu teknik pembelajaran diterapkan dan bagaimana hasil yang diinginkan dapat dicapai. Penelitian ini mengambil bentuk penelitian tindakan sekolah (PTS) yaitu peningkatan kinerja guru melalui kunjungan kelas dalam rangka mengimplementasikan standar proses, yang terdiri dari 2 siklus dan masing- masing siklus terdiri dari 4 tahap yaitu :

(I) tahap perencanaan program tindakan,

(2) pelaksanaan program tindakan,

(3) pengamatan program,

(4) refleksi.

\section{B. Tempat dan Waktu Penelitian}

I. Tempat Penelitian

Penelitian ini akan dilaksanakan di SDN-I Pangkalan Satu. Pemilihan tempat ini di mana penulis bertugas sebagai kepala sekolah di sekolah tersebut.

\section{Waktu Penelitian}

Penelitian akan dilakukan pada semester Ganjil tahun 2019/2020 di SDN-I Pangkalan Satu. Berikut adalah jadwal kegiatan dan waktu penelitian:

Tabel I jadwal kegiatan dan waktu penelitian

\begin{tabular}{|c|c|c|c|c|c|c|c|c|c|c|c|c|c|c|c|c|c|}
\hline \multirow[t]{2}{*}{ No } & \multirow[t]{2}{*}{ Kegiatan } & \multicolumn{4}{|c|}{$\begin{array}{l}\text { Septem } \\
\text { Minggu ke }\end{array}$} & \multicolumn{4}{|c|}{$\begin{array}{l}\text { Okto } \\
\text { Minggu ke }\end{array}$} & \multicolumn{4}{|c|}{$\begin{array}{l}\text { Nov } \\
\text { Minggu ke }\end{array}$} & \multicolumn{4}{|c|}{$\begin{array}{l}\text { Des } \\
\text { Minggu ke }\end{array}$} \\
\hline & & $I$ & $\frac{00}{2}$ & 3 & 4 & $\mathrm{I}$ & $\frac{00}{2}$ & 3 & 4 & $\mathrm{I}$ & 2 & 3 & 4 & $\mathrm{I}$ & 2 & 3 & 4 \\
\hline $\mathrm{I}$ & Observasi awal & & $\sqrt{ }$ & $\sqrt{ }$ & & & & & & & & & & & & & \\
\hline 2 & $\begin{array}{l}\text { Wawancara dengan } \\
\text { beberapa guru }\end{array}$ & & & & $\sqrt{ }$ & & & & & & & & & & & & \\
\hline 3 & $\begin{array}{ll}\text { Berdiskusi dengan } \\
\text { guru-guru }\end{array}$ & & & & $\sqrt{ }$ & & & & & & & & & & & & \\
\hline 4 & $\begin{array}{lr}\text { Briefing } & \text { dengan } \\
\text { guru-guru } & \text { terkait } \\
\text { akan } & \mathrm{di} \\
\text { laksanakannya } & \\
\text { penelitian } & \end{array}$ & & & & & $\sqrt{ }$ & $\sqrt{ }$ & & & & & & & & & & \\
\hline 5 & $\begin{array}{l}\text { Menyusun judul } \\
\text { penelitian }\end{array}$ & & & & & & & $\sqrt{ }$ & & & & & & & & & \\
\hline 6 & $\begin{array}{l}\text { Mengumpulkan } \\
\text { refrensi }\end{array}$ & & & & & & & & $\sqrt{ }$ & $\sqrt{ }$ & & & & & & & \\
\hline 7 & Menyusun Proposal & & & & & & & & $\sqrt{ }$ & $\sqrt{ }$ & & & & & & & \\
\hline 8 & $\begin{array}{l}\text { Menyusun } \\
\text { instrument }\end{array}$ & & & & & & & & & & $\sqrt{ }$ & & & & & & \\
\hline 9 & Pelaksanaan Siklus I & & & & & & & & & & $\sqrt{ }$ & & & & & & \\
\hline 10 & Pelaksanaan Siklus II & & & & & & & & & & & $\sqrt{ }$ & & & & & \\
\hline II & Analisis Hasil & & & & & & & & & & & & $\sqrt{ }$ & & & & \\
\hline 12 & Menyusun Laporan & & & & & & & & & & & & & $\sqrt{ }$ & $\sqrt{ }$ & & \\
\hline
\end{tabular}

\section{Subjek Penelitian}

Penelitian ini dilaksanakan di SDN-I Pangkalan Satu dengan subjek penelitian adalah guru yang ada di 
Mansyur. Peningkatan Kompetensi Guru Dalam Penginputan Penilaian E-Raport Melalui Pelatihan TIK DI SDN-I Pangkalan Satu Tahun Pelajaran 2019/2020"

sekolah ini, dan di ambil 10 guru. Berikut adalah subjek penelitian ini:

Tabel 2 Subjek Penelitian

\begin{tabular}{|c|l|l|}
\hline NO & \multicolumn{1}{|c|}{ NAMA GURU } & JABATAN GURU \\
\hline I & SITI KAYATUN & Guru Kelas \\
\hline 2 & SUWARSI & Guru Kelas \\
\hline 3 & MULYONO & Guru Kelas \\
\hline 4 & KASNO & Guru Kelas \\
\hline 5 & RATIM & Guru Kelas \\
\hline 6 & WARDANINGSIH & Guru Kelas \\
\hline 7 & DIYAH SETYAWATI & Guru PAI \\
\hline 8 & IDAWATI & Guru Kelas \\
\hline 9 & NUR EKA NOVIANTI & Guru Kelas \\
\hline I0 & JUMADI & Guru Kelas \\
\hline
\end{tabular}

\section{Prosedur Penelitian}

\section{Siklus I}

a. Perencanaan

Pada tahap ini peneliti merumuskan dan mempersiapkan: rencana jadwal pelaksanaan tindakan, rencana pelaksanaan pelatihan TIK, membuat lembar observasi, dan mempersiapkan kelengkapan lain yang diperlukan dalam rangka analisis data.

b. Tahap Pelaksanaan

Pelaksanaan pelatihan TIK Siklus I dilaksanakan selama $2 \times$ pertemuan dalam seminggu. Pelaksanaan tindakan pada dasarnya disesuaikan dengan setting tindakan yang telah ditetapkan dalam rencana pelaksanaan.

c. Pengamatan

Setelah proses pelatihan TIK selesai maka dilakukan pengamatan selama seminggu terhadap guru. Pengamatan dilakukan untuk mengetahui peningkatan kompetensi guru dalam penginputan penilaian E-Raport

\section{d. Refleksi}

Refleksi merupakan kegiatan menganalisis semua data atau informasi yang dikumpulkan dari penelitian tindakan yang dilaksanakan, sehingga dapat diketahui berhasil atau tidaknya tindakan yang telah dilaksanakan dengan tujuan yang diharapkan.

\section{E. Teknik Pengumpulan Data}

Pengumpulan data dalam penelitian ini menggunakan tiga teknik yaitu :

\section{Wawancara}

Wawancara merupakan merupakan sebuah percakapan langsung antara si peneliti dengan responden yang diteliti yang dilakukan dengan tujuan untuk memperoleh informasi yang dibutuhkan. Dalam penelitian inti peneliti menggunakan pedoman wawancara yang sifatnya terbuka yang dimaksudkan agar peneliti tidak keluar dari apa yang sedang diteliti.

Untuk lebih memantapkan hasil wawancara peneliti melakukan cross check dengan melakukan wawancara selain dengan kepala sekolah juga dengan guru.

\section{Observasi}

Observasi adalah pengamatan dan pencatatan yang sistematis terhadap gejala- gejala yan diteliti (Husaini Usman dan Purnomo Setiady Akbar, 200l: 54). Dari pengertian tersebut sudah jelas bahwa observasi merupakan pengamatan langsung terhadap suatu kegiatan yang sedang dilakukan. Sehingga, dalam penelitian ini peneliti melakukan pengamatan secara langsung terhadap kompetensi guru dalam penginputan penilaian E-Raport. Teknik ini digunakan untuk mendapatkan data yang cermat dan faktual.

Obsevasi ini dilakukan secara berkelanjutan dengan memperhatikan situasi dan kondisi yang terjadi di sekolah tersebut, sehingga akan diperoleh informasi yang sesuai dengan kebutuhan peneliti.

\section{Studi dokumentasi}

Penelitian kualitatif selain menggunakan observasi dan wawancara dalam mencari sumber data, tetapi masih perlu dilakukan dengan studi dokumentasi yang dilakukan dengan melihat, mengamati dan menganalisis dokumen-dokumen agar mampu menguatkan hasil yang diperoleh dengan melakukan obsevasi dan wawancara. Peneliti melakukan studi dokumentasi untuk dimanfaatkan sebagai bahan triangulasi untuk pengecekan kesesuaian data.

\section{F. Instrumen Penelitian}

Menurut Nurul Zuriah (2007: 168) dikatakan bahwa instrumen penelitian merupakan alat bantu bagi peneliti dalam mengumpulkan data. Dalam melakukan penelitian, seorang peneliti harus mampu membuat instrumen sendiri termasuk mengkaji indikator sejelasjelasnya sehingga bisa diukur dan menghasilkan data yang diinginkan. Instruman yang digunakan peneliti dalam melakukan penelitian kualitatif adalah si peneliti itu sendiri sebab dibutuhkan pengamatan langsung oleh peneliti untuk melihat objek di lapangan. Sehingga, peneliti bisa melakukan pengamatan secara mendalam.

Dalam penelitian ini peneliti menggunakan instrumen penelitian dengan wawancara, observasi dan studi dokumentasi.

\section{HASIL PENELITIAN DAN PEMBAHASAN}

\section{A. Hasil Penelitian}

\section{Hasil Penelitian Pra Tindakan}

Penelitian ini dilaksanakan di SDN-I Pangkalan Satu dengan subjek penelitian adalah guru yang ada di sekolah ini, baik yang sudah pegawai negeri sipil maupun yang masih wiyata bakti. Dalam hal ini di ambil 10 guru.

Adapun kompetensi guru dalam penginputan penilaian E-Raport yang ada di SDN-I Pangkalan Satu adalah sebagai berikut: 
Berikut adalah hasil penilaian pra tindakan tentang kompetensi guru dalam penginputan penilaian E-Raport

Tabel 3
Hasil Penilaian Kompetensi Guru dalam Penginputan Penilaian E-Raport Pra Tindakan

Petunjuk: Penilai memberi nilai dan isikan pula secara jelas hal-hal penting/menarik pada saat penelitian

\begin{tabular}{|l|l|l|l|l|l|l|}
\hline \multirow{2}{*}{ Guru } & \multicolumn{9}{|l|}{ Aspek yang dinilai } & \multirow{2}{*}{ JmI Skor } & \multirow{2}{*}{ Kategori } \\
\cline { 2 - 6 } & $\mathrm{I}$ & 2 & 3 & 4 & & \\
\hline SITI KAYATUN & $\mathrm{I}$ & 2 & $\mathrm{I}$ & $\mathrm{I}$ & 5 & $\mathrm{~B}$ \\
\hline SUWARSI & $\mathrm{I}$ & $\mathrm{I}$ & $\mathrm{I}$ & $\mathrm{I}$ & 4 & $\mathrm{C}$ \\
\hline MULYONO & $\mathrm{I}$ & $\mathrm{I}$ & $\mathrm{I}$ & $\mathrm{I}$ & 4 & $\mathrm{C}$ \\
\hline KASNO & $\mathrm{I}$ & $\mathrm{I}$ & $\mathrm{I}$ & $\mathrm{I}$ & 4 & $\mathrm{C}$ \\
\hline RATIM & $\mathrm{I}$ & $\mathrm{I}$ & $\mathrm{I}$ & $\mathrm{I}$ & 4 & $\mathrm{C}$ \\
\hline WARDANINGSIH & $\mathrm{I}$ & $\mathrm{I}$ & $\mathrm{I}$ & $\mathrm{I}$ & 4 & $\mathrm{C}$ \\
\hline DIYAH SETYAWATI & $\mathrm{I}$ & $\mathrm{I}$ & $\mathrm{I}$ & $\mathrm{I}$ & 4 & $\mathrm{C}$ \\
\hline IDAWATI & $\mathrm{I}$ & $\mathrm{I}$ & $\mathrm{I}$ & $\mathrm{I}$ & 4 & $\mathrm{C}$ \\
\hline NUR EKA NOVIANTI & $\mathrm{I}$ & 2 & $\mathrm{I}$ & $\mathrm{I}$ & 5 & $\mathrm{~B}$ \\
\hline JUMADI & $\mathrm{I}$ & $\mathrm{I}$ & $\mathrm{I}$ & $\mathrm{I}$ & 4 & $\mathrm{C}$ \\
\hline Skor rata-rata & $\mathrm{I}$ & $\mathrm{I} .12$ & $\mathrm{I}$ & $\mathrm{I}$ & 4.12 & \\
\hline
\end{tabular}

Keterangan:

\begin{tabular}{|l|l|}
\hline No & \multicolumn{1}{|c|}{ Aspek yang dinilai } \\
\hline I & $\begin{array}{l}\text { Guru mampu merencanakan penilaian pengetahuan, keterampilan, } \\
\text { sikap spiritual, dan sikap sosial }\end{array}$ \\
\hline 2 & $\begin{array}{l}\text { Guru mampu menginput nilai pengetahuan, keterampilan, sikap } \\
\text { spiritual, dan sikap sosial }\end{array}$ \\
\hline 3 & Guru mampu menyimpan proses deskripsi nilai \\
\hline 4 & Guru dapat mengirim nilai akhir \\
\hline
\end{tabular}

A : Amat Baik (Skor 3)
B: Baik (Skor 2)
C: Cukup (Skor I)

Skor Maksimal: 3X 4= 12

Kriteria Penilaian

A: 9-12: Kompetensi guru dalam penginputan penilaian E-Raport Amat Baik

B:5-8 : Kompetensi guru dalam penginputan penilaian E-Raport Baik

$\mathrm{C}: \leq 4$ : Kompetensi guru dalam penginputan penilaian E-Raport Cukup

\section{Diagram I Hasil Penilaian Pra Siklus}

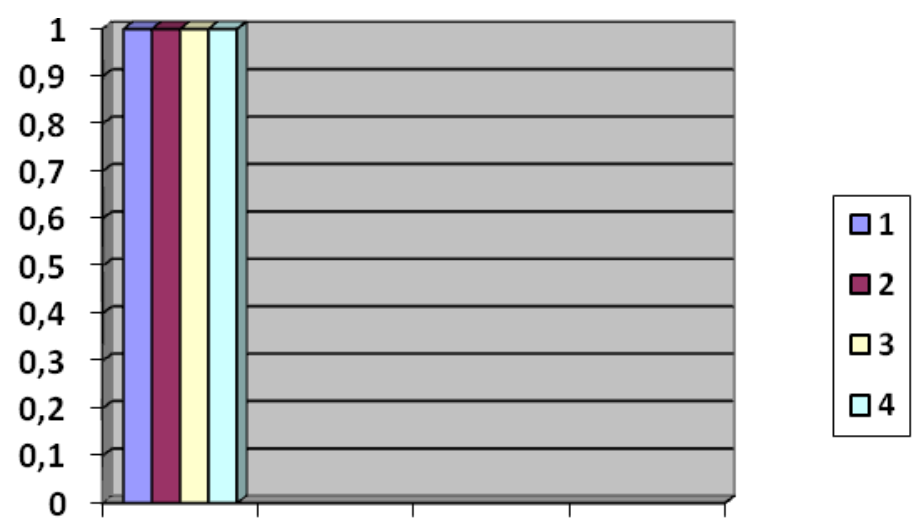

Nilai rata-

rata

\section{Pelaksanaan Siklus I}

a. Tahap Perencanaan

Pada perencanaan, peneliti melaksanakan program pelatihan TIK dalam meningkatkan kompetensi guru dalam penginputan penilaian E-Raport.

Pada tahap perencanaan peneliti menyiapkan hal berikut:

$\square$ Rencana jadwal pelaksanaan tindakan, 
$\square$ Rencana pelaksanaan pelatihan TIK,

$\square$ Membuat lembar observasi, dan

$\square$ Mempersiapkan kelengkapan lain yang diperlukan dalam rangka analisis data.

b. Tahap Pelaksanaan

Adapun pelaksanannya adalah sebagai berikut:

\section{Jadwal Pelatihan TIK Siklus I}

Pelaksanaan : Jumat -Sabtu ( I5 dan 16 November 2019)

Lokasi $\quad$ :Ruang Laboratorium TIK

Waktu : $\quad$ I3.00 s.d. selesai

Hari : Jum'at, 15 November 2019

\begin{tabular}{|l|l|l|l|}
\hline No & \multicolumn{1}{|c|}{ Waktu } & \multicolumn{1}{|c|}{ Acara } & \multicolumn{1}{c|}{ Narasumber } \\
\hline 2 & $13.00-13.30$ & Pembukaan & Kepala Sekolah \\
\hline 3 & $13.30-14.30$ & Materi : Cara login ke aplikasi e-Rapor & Nara Sumber \\
\hline 5 & $14.30-15.30$ & Materi :Merencanakan Penilaian Harian & Nara Sumber \\
\hline 8 & $15.30-16.00$ & Penyimpulan Materi Hari I & Nara Sumber \\
\hline
\end{tabular}

Hari : Sabtu, 16 November 2019

\begin{tabular}{|l|l|l|l|}
\hline No & \multicolumn{1}{|c|}{ Waktu } & \multicolumn{1}{|c|}{ Acara } & \multicolumn{1}{|c|}{ Narasumber } \\
\hline 2 & $13.00-13.30$ & Pembukaan & Kepala Sekolah \\
\hline 3 & $13.30-14.30$ & Materi : Menginput Nilai & Nara Sumber \\
\hline 5 & $14.30-15.30$ & $\begin{array}{l}\text { Materi : Menginput nilai tengah semester } \\
\text { (PTS) dan nilai akhir semester (PAS) }\end{array}$ & Nara Sumber \\
\hline 8 & $15.30-16.30$ & Praktek penginputan penilaian E-Raport & Nara Sumber \\
\hline
\end{tabular}

\section{c. Pengamatan}

Setelah kegiatan pelatihan TIK berlangsung, peneliti bertindak sebagai supervisor yang bertugas mengamati kompetensi guru dalam penginputan penilaian E-Raport dengan mengisi lembar supervisi yang telah disusun sebelum melaksanakan kegiatan penelitian. Hal ini dilakukan untuk mengetahui peningkatan kompetensi guru dalam penginputan penilaian E-Raport.

Berikut adalah hasil penilaian siklus I:

\section{Tabel 4}

Hasil Penilaian Siklus I

Petunjuk: Penilai memberi nilai dan isikan pula secara jelas hal-hal penting/menarik pada saat penelitian

\begin{tabular}{|c|c|c|c|c|c|c|}
\hline \multirow[t]{2}{*}{ Guru } & \multicolumn{4}{|c|}{ Aspek yang dinilai } & \multirow[t]{2}{*}{ Jml Skor } & \multirow[t]{2}{*}{ Kategori } \\
\hline & $\mathrm{I}$ & 2 & 3 & 4 & & \\
\hline SITI KAYATUN & 2 & 2 & 2 & $\mathrm{I}$ & 7 & $\mathrm{~B}$ \\
\hline SUWARSI & 2 & 2 & $\mathrm{I}$ & $\mathrm{T}$ & 6 & $\mathrm{C}$ \\
\hline MULYONO & 2 & 2 & 2 & $\mathrm{I}$ & 7 & $\mathrm{C}$ \\
\hline KASNO & 2 & 2 & 2 & $\mathrm{I}$ & 7 & $\mathrm{C}$ \\
\hline RATIM & 2 & 2 & 2 & $\mathrm{~T}$ & 7 & $\mathrm{C}$ \\
\hline WARDANINGSIH & 2 & 2 & 2 & I & 7 & $\mathrm{C}$ \\
\hline DIYAH SETYAWATI & 2 & 2 & 2 & $\mathrm{I}$ & 7 & C \\
\hline IDAWATI & 2 & 2 & I & I & 6 & C \\
\hline NUR EKA NOVIANTI & 2 & 2 & 2 & $\mathrm{~T}$ & 7 & $\mathrm{~B}$ \\
\hline JUMADI & 2 & 2 & I & I & 6 & C \\
\hline Skor rata-rata & 2 & 2 & 1.75 & $\mathrm{~T}$ & 6.75 & \\
\hline
\end{tabular}

Keterangan:

\begin{tabular}{|l|l|}
\hline No & \multicolumn{1}{|c|}{ Aspek yang dinilai } \\
\hline I & $\begin{array}{l}\text { Guru mampu merencanakan penilaian pengetahuan, keterampilan, } \\
\text { sikap spiritual, dan sikap sosial }\end{array}$ \\
\hline 2 & $\begin{array}{l}\text { Guru mampu menginput nilai pengetahuan, keterampilan, sikap } \\
\text { spiritual, dan sikap sosial }\end{array}$ \\
\hline 3 & Guru mampu menyimpan proses deskripsi nilai \\
\hline 4 & Guru dapat mengirim nilai akhir \\
\hline
\end{tabular}
A : Amat Baik (Skor 3)
B: Baik (Skor 2)
C: Cukup (Skor I)
Skor Maksimal: 3X 4= 12 
Kriteria Penilaian

A: 9- 12 : Kompetensi guru dalam penginputan penilaian E-Raport Amat Baik

B:5-8 : Kompetensi guru dalam penginputan penilaian E-Raport Baik

$\mathrm{C}: \leq 4$ : Kompetensi guru dalam penginputan penilaian E-Raport Cukup

\section{Diagram 2 Hasil Penilaian Siklus I}

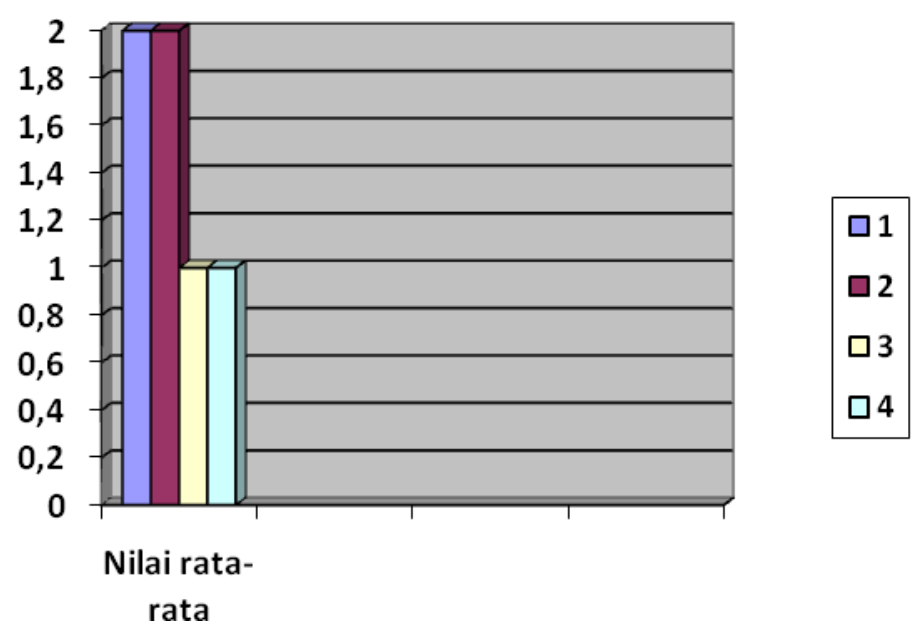

\section{c. Refleksi}

Data penelitian tindakan sekolah yang diperoleh dari hasil observasi sikap guru dalam praktek penginputan penilaian E-Raport pada siklus I, hasilnya termasuk katagori "baik" dengan rata-rata aspek I yakni 2, aspek 2 yakni 2, aspek 3 yakni I, dan aspek 4 yakni I. Hal ini menunjukkan bahwa kompetensi guru dalam penginputan penilaian E-Raport sudah baik, akan tetapi perlu peningkatan.

Dengan adanya hasil observasi dan penilaian pada kegiatan siklus I maka peneliti melakukan refleksi. Dari refleksi terhadap seluruh kegiatan pada siklus I, maka ditemukan beberapa hambatan yang mengakibatkan belum optimalnya kompetensi guru dalam penginputan penilaian E-Raport.

Adapun hambatan-hambatan tersebut, antara lain guru belum sepenuhnya maksimal dalam memberikan materi kewirausahaan kepada siswa, guru belum membimbing secara maksilam dalam hal praktek berwirausaha bagi siswa. Hal ini terlihat dalam pelaksanaan pembelajaran yaitu guru belum maksimal dalam memberikan materi kewirausahaan.

\section{B. Pembahasan}

Berdasarkan hasil analisis dan pembahasan siklus I dan siklus II tersebut di atas, maka dapat disimpulkan bahwa: Ada peningkatan kompetensi guru dalam penginputan penilaian E-Raport.

Hasil penilaian pra tindakan tentang kompetensi guru dalam penginputan penilaian E-Raport di dapatkan data bahwa guru belum mampu dalam penginputan penilaian E-Raport.

Data penelitian tindakan sekolah yang diperoleh dari hasil observasi sikap guru dalam praktek penginputan penilaian E-Raport pada siklus I, hasilnya termasuk katagori "baik" dengan rata-rata aspek I yakni 2, aspek 2 yakni 2, aspek 3 yakni I, dan aspek 4 yakni I. Hal ini menunjukkan bahwa kompetensi guru dalam penginputan penilaian E-Raport sudah baik, akan tetapi perlu peningkatan.

Dengan adanya hasil observasi dan penilaian pada kegiatan siklus I maka peneliti melakukan refleksi. Dari refleksi terhadap seluruh kegiatan pada siklus I, maka ditemukan beberapa hambatan yang mengakibatkan belum optimalnya kompetensi guru dalam penginputan penilaian E-Raport.

\section{PENUTUP}

\section{A. Kesimpulan}

Hasil penilaian pra tindakan tentang kompetensi guru dalam penginputan penilaian E-Raport di dapatkan data bahwa guru belum mampu dalam penginputan penilaian E-Raport.

Data penelitian tindakan sekolah yang diperoleh dari hasil observasi sikap guru dalam praktek penginputan penilaian E-Raport pada siklus I, hasilnya termasuk katagori "baik" dengan rata-rata aspek I yakni 2, aspek 2 yakni 2, aspek 3 yakni I, dan aspek 4 yakni I. Hal ini menunjukkan bahwa kompetensi guru dalam penginputan penilaian E-Raport sudah baik, akan tetapi perlu peningkatan.

Dengan adanya hasil observasi dan penilaian pada kegiatan siklus I maka peneliti melakukan refleksi. Dari refleksi terhadap seluruh kegiatan pada siklus I, maka ditemukan beberapa hambatan yang mengakibatkan belum optimalnya kompetensi guru dalam penginputan penilaian E-Raport.

\section{B. Saran}

Peneliti membuat saran-saran berikut:

I. Untuk Guru 
Dengan meningkatkan kompetensi guru dalam penginputan penilaian E-Raport sudah tentu akan membawa dampak positif baik bagi diri guru sendiri dan juga bagi para siswa.

2. Untuk Para Kepala sekolah

Bagi para Kepala sekolah teruslah mencari dan menerapkan program-program yang pas dan cocok untuk memperbaiki kualitas pengajar di sekolah. Hal ini akan menunjang sekali pada tercapainya tujuan pembelajaran.

3. Bagi kalangan umum

Bagi kalangan umum bisa membaca dan menjadikan refrensi hasil tulisan saya ini untuk memilih metode dalam meningkatkan Kompetensi guru dalam penginputan penilaian E-Raport.

\section{DAFTAR PUSTAKA}

Sumber : Pengenalan Teknologi Informasi , “Abdul kadir dan Terra Ch Triwahyuni, Penerbit Andi

Sumber:http://id.shvoong.com/society-andnews/20I25I5-pengertian-teknologiinformasi/\#ixzz27wApJEYJ

Haryanto, Edy. (2008). Teknologi Informasi dan Komunikasi: Konsep dan Perkembangannya. Pemanfaatan Teknologi Informasi dan Komunikasi Sebagai Media Pembelajaran

Kasianto, I Wayan 2004 Meningkatkan Prestasi
Belajar Siswa $\begin{gathered}\text { dengan Pendekatan Diskusi } \\ \text { Kelompok.Laporan } \\ \text { dipublikasikan }\end{gathered}$

Sutrisno Hadi, 2000. Metodelogi Penelitian. Yogyakarta: Andi

Hadari Nawawi, Administrasi Pendidikan, Jakarta: PT Gunung Agung, 1994,

Mukhtar dan Iskandar, Orientasi Baru Supervisi Pendidikan, Jakarta: Gaung Persada Press, 2009,

Arikunto, Manajemen Pendidikan, Yogyakarta: Aditya Media, 2009

Arikunto, Suharsimi, 2004, Dasar-dasar Supervisi, Jakarta, PT. Rineka Cipta.

Pandong, A. (2003). Jabatan Fungsional Pengawas. Badan Diklat Depdagri \& Diklat Depdiknas.

Muid, F. (2003). Standar Pelayanan Pendidikan. Badan Diklat Depdagri \& Diklat Depdiknas. 